\title{
Complete genome sequence of Corynebacterium pseudotuberculosis biovar ovis strain P54B96 isolated from antelope in South Africa obtained by rapid next generation sequencing technology
}

Syed Shah Hassan', Luis Carlos Guimarães ${ }^{1}$, Ulisses de Pádua Pereira ${ }^{5}$, Arshad Islam ${ }^{6}$, Amjad Ali ${ }^{1}$, Syeda Marriam Bakhtiar ${ }^{1}$, Dayana Ribeiro ${ }^{1}$, Anderson Rodrigues dos Santos ${ }^{1}$, Siomar de Castro Soares ${ }^{1}$, Fernanda Dorella ${ }^{1}$, Anne Cybelle Pinto ${ }^{1}$, Maria Paula Cruz Schneider ${ }^{2}$, Maria Silvanira Barbosa ${ }^{2}$, Síntia Almeida ${ }^{1}$, Vinícius Abreu ${ }^{1}$, Flávia Aburjaile ${ }^{1}$, Adriana Ribeiro Carneiro ${ }^{2}$, Louise Teixeira Cerdeira ${ }^{2}$, Karina Fiaux ${ }^{1}$, Eudes Barbosa ${ }^{1}$, Carlos Diniz ${ }^{1}$, Flavia S. Rocha ${ }^{1}$, Rommel Thiago Jucá Ramos ${ }^{2}$, Neha Jain ${ }^{4}$, Sandeep Tiwari ${ }^{4}$, Debmalya Barh ${ }^{4}$, Anderson Miyoshi', Borna Müller ${ }^{3}$, Artur Silva ${ }^{2 *}$, Vasco Azevedo ${ }^{1 *}$

${ }^{1}$ Laboratório de Genética Celular e Molecular, Departamento de Biologia Geral, Instituto de Ciências Biológicas (ICB), Universidade Federal de Minas Gerais, Belo Horizonte, Brazil

${ }^{2}$ Instituto de Ciências Biológicas, Universidade Federal do Pará, Belém, PA, Brazil

${ }^{3}$ DST/NRF Centre of Excellence for Biomedical Tuberculosis Research/MRC Centre for Molecular and Cellular Biology, Division of Molecular Biology and Human Genetics, Faculty of Health Sciences, Stellenbosch University, Cape Town, South Africa

${ }^{4}$ Centre for Genomics and Applied Gene Technology, Institute of Integrative Omics and Applied Biotechnology (IIOAB), Nonakuri, Purba Medinipur, West Bengal, India

${ }^{5}$ Departamento de Medicina Veterinária, Universidade Federal de Lavras, Lavras, Brazil

${ }^{6}$ Instituto de Ciências Exatas (ICEX), Universidade Federal de Minas Gerais, Belo Horizonte, MG, Brazil

*Corresponding Authors: Prof. Vasco Azevedo (vasco@icb.ufmg.br) and Prof. Artur Silva (asilva@ufpa.br)

Keywords: biovar ovis, Gram-positive pathogen, caseous lymphadenitis/cheesy gland disease, liver lesion, Antelope, genome sequencing, lon Torrent.

The Actinobacteria, Corynebacterium pseudotuberculosis strain P54B96, a nonmotile, nonsporulating and a mesophile bacterium, was isolated from liver, lung and mediastinal lymph node lesions in an antelope from South Africa. This strain is interesting in the sense that it has been found together with non-tuberculous mycobacteria (NTMs) which could nevertheless play a role in the lesion formation. In this work, we describe a set of features of C. pseudotuberculosis P54B96, together with the details of the complete genome sequence and annotation. The genome comprises of 2.34 Mbp long, single circular genome with 2,084 protein-coding genes, 12 rRNA, 49 tRNA and 62 pseudogenes and a G+C content of $52.19 \%$. The analysis of the genome sequence provides means to better understanding the molecular and genetic basis of virulence of this bacterium, enabling a detailed investigation of its pathogenesis.

\section{Introduction}

Caseous lymphadenitis (CLA) or cheesy gland [1] is highly prevalent in many regions of the world, resulting in huge and significant economic losses in agribusiness since it is responsible for a decrease in wool production and carcass quality [2]. Mainly small ruminant populations like sheep and goats, and other mammals, such as bovines, pigs, deer, ovines, equines, and even, though rarely, in camels and humans, are the victims of Corynebacterium pseudotuberculosis [3-6]. The disease is characterized by the presence of caseous necrosis in external and/or internal lymph nodes $[1,7]$. Ulcerative lymphangitis, which is confined to the lymph vessels of extremities particularly the hind legs, is a disease caused by this bacterium in the horse $[8,9]$. The bacterium in 
some cases of human lymphadenitis, clinical strains are occasionally recovered [10]. The prevalence of CLA in the animals scattered throughout the globe needs effective measures to control the onset of the disease in herds along with the treatment of infected animals. Numerous reports have been published worldwide where mainly small ruminants are the carriers of the $C$. pseudotuberculosis. They include South Africa, Brazil, United States of America, Canada, Australia, New Zealand, United Kingdom and Egypt [11-18]. Histopathological examination of antelope carcasses from a South African game reserve, a part of their routine meat inspection, showed tuberculosis-like lesions. These lesions were characterized by the presence of encapsulated necrogranulomatous inflammation similar to CLA within the pulmonary tissues, in bronchial lymph nodes, liver, kidney and some other organs of the antelopes [11]. Diseases caused by the bacterium C. pseudotuberculosis are presented in various clinical forms as sheep and goats, affected with CLA [19]. Among the affected animal population, the increased prevalence and rapid transmission of the disease necessitates certain measures to control disease dissemination and prevent the nearby wildlife. The analysis of the genome sequence will help us better understand the molecular and genetic basis of virulence of this bacterium.

\section{Classification and Features}

C. pseudotuberculosis is a facultative intracellular pathogen showing pleomorphic forms like coccoids and filamentous rods, with sizes ranging between 0.5-0.6 $\mu \mathrm{m}$ and 1.0-3.0 $\mu \mathrm{m}$ [2]. Cells are described as Gram-positive, non-encapsulated, non-motile, non-sporulating and possessing fimbriae $[12,20]$. The bacterium was first isolated in 1888 from bovine farcy by Nocard and was first completely described by Preisz, showing its resemblance to diphtheria bacillus. The organism has been previously named Bacillus pseudotuberculosis ovis; Bacillus pseudo-tuberculosi and, Corynebacterium ovis [8,21]. It is a facultative anaerobe. The best growth temperature and $\mathrm{pH}$ are $37^{\circ} \mathrm{C}$ and 7.0-7.2, respectively [17,22]. After initially growing sparsely, strain P54B96 forms organized clumps on the agar surface, demonstrating dry opaque and concentrically ringed colonies. In liquid media it develops a granular deposit with a surface pellicle $[8,22,23]$.
There exist two biotypes of C. pseudotuberculosis according to their capability of nitrate reduction. Bacteria capable of performing the reduction of nitrate are classified into biovar equi (nitrate reduction positive; mainly isolated from horses and cattle) while the bacteria which can not perform the reduction of nitrate, pertain to biovar ovis (nitrate reduction negative; frequently isolated from sheep and goats) $[2,24]$. Corynebacteria possess an unusual structural organization in their cell envelope, similar to the Gram-negative bacteria [25] and belong to a very heterogeneous CMNR (Corynebacterium, Mycobacterium, Nocardia and Rhodococcus) group that shares characteristics including an outer lipid layer, mycolic acids in the cell wall along with with its derivatives including phospholipids and lipomannans [4]. Marchand et al. (2012) and others reported the presumed mycomembrane, an atypical outer membrane, pore-forming proteins like PorA and PorB, mycoloyltransferases, the so-called fibronectinbinding proteins like cMytA-D and $\mathrm{cMytF}$, several lipoproteins and some unknown putative Cterminal hydrophobic anchored proteins [26]. Analysis of amino acids and amino sugars of cell wall peptidoglycan reveals the presence of meso-diaminopimelic acid (meso-DAP). Major cell wall sugars are arabinose and galactose $[17,27]$. In addition, high and low molecular mass glucan, arabinomannan and lipoglycan also make part of the cell wall. Trehalose dimycolate (TDM) and trehalose monomycolate (TMM) are soluble cell envelope lipids [28]. Biochemically, all strains produce acid from glucose, maltose, fructose, sucrose and mannose $[21,22]$. This bacterium is catalase positive and phospholipase $\mathrm{D}$, beta-hemolysis and oxidase negative $[23,29]$.

Figure 1 shows the phylogenetic neighborhood of $C$. pseudotuberculosis strain P54B96 in an rрoB gene ( $\beta$ subunit of RNA polymerase) based tree. It has recently been shown that phylogenetic analysis for the identification of Corynebacterium as well as other CMNR species based on $r p o B$ gene sequences are more accurate than analyses based on 16S rRNA $[42,43]$. The $r p o B$ gene sequences of reference strains from the CMNR group were used to construct the phylogenetic tree. 


\section{Genome sequencing and annotation Genome project history}

This organism was selected for sequencing on the basis of its phylogenetic position. The genome project is deposited in the Genomes OnLine Database [44] and the complete genome sequence is available in GenBank (CP003385.1). Sequencing, finishing and annotation were performed by the Rede Paraense de Genômica e Proteômica (RPGP), Pará, Brazil. A summary of the project information is shown in Table 2.

\section{Growth conditions and DNA isolation}

C. pseudotuberculosis P54B96 was grown in brainheart-infusion broth (BHI-HiMedia Laboratories Pvt. Ltda, India) in shake culture at $140 \mathrm{rpm}$ and at $37^{\circ} \mathrm{C}$. Extraction of chromosomal DNA was performed by using $50 \mathrm{~mL}$ of $48-72 \mathrm{~h}$ culture of $C$. pseudotuberculosis, centrifuged at $4{ }^{\circ} \mathrm{C}$ and $2000 \times \mathrm{g}$ for $20 \mathrm{~min}$. Re-suspension of cell pellets was done in $1 \mathrm{~mL}$ Tris/EDTA/NaCl [10 mM Tris/HCl (pH7.0), 10 mM EDTA (pH8.0), and $300 \mathrm{mM} \mathrm{NaCl}$ ] for recentrifugation under the same conditions. The pellets were re-suspended in $1 \mathrm{~mL} \mathrm{TE} /$ lysozyme [25 mM Tris/HCl (pH8.0), 10 mM EDTA (pH8.0), 10 mM
$\mathrm{NaCl}$, and $10 \mathrm{mg}$ lysozyme/mL]. The sample was then incubated at $37^{\circ} \mathrm{C}$ for $30 \mathrm{~min}$ and then $30 \mu \mathrm{L}$ of $30 \%(\mathrm{w} / \mathrm{v})$ sodium N- lauroyl-sarcosine (Sarcosyl) was added to it, incubated for $20 \mathrm{~min}$ at $65^{\circ} \mathrm{C}$, followed by incubation for $5 \mathrm{~min}$ at $4{ }^{\circ} \mathrm{C}$. Purification of DNA with phenol/chloroform/isoamylalcohol (25:24:1) was followed by precipitation with ethanol. DNA concentration was determined by spectrophotometer, and the DNA was visualized in ethidium bromide-stained $0.7 \%$ agarose gel.

\section{Genome sequencing and assembly}

The complete genome sequence of $C$. pseudotuberculosis P54B96 was obtained using the Ion Torrent PGM (Life Technologies) Sequencing Platform. A total, of 562,812 reads were generated, each with a mean size of 112 nts usable sequence (35-fold coverage). Furthermore, a hybrid de novo assembly approach was applied using 376,642 Ion filtered reads (19-fold coverage). This was carried out after quality filtering process during which reads representing an average Phred quality of less than 20, were removed. This strategy allowed closing gaps without bench work time cost [45].

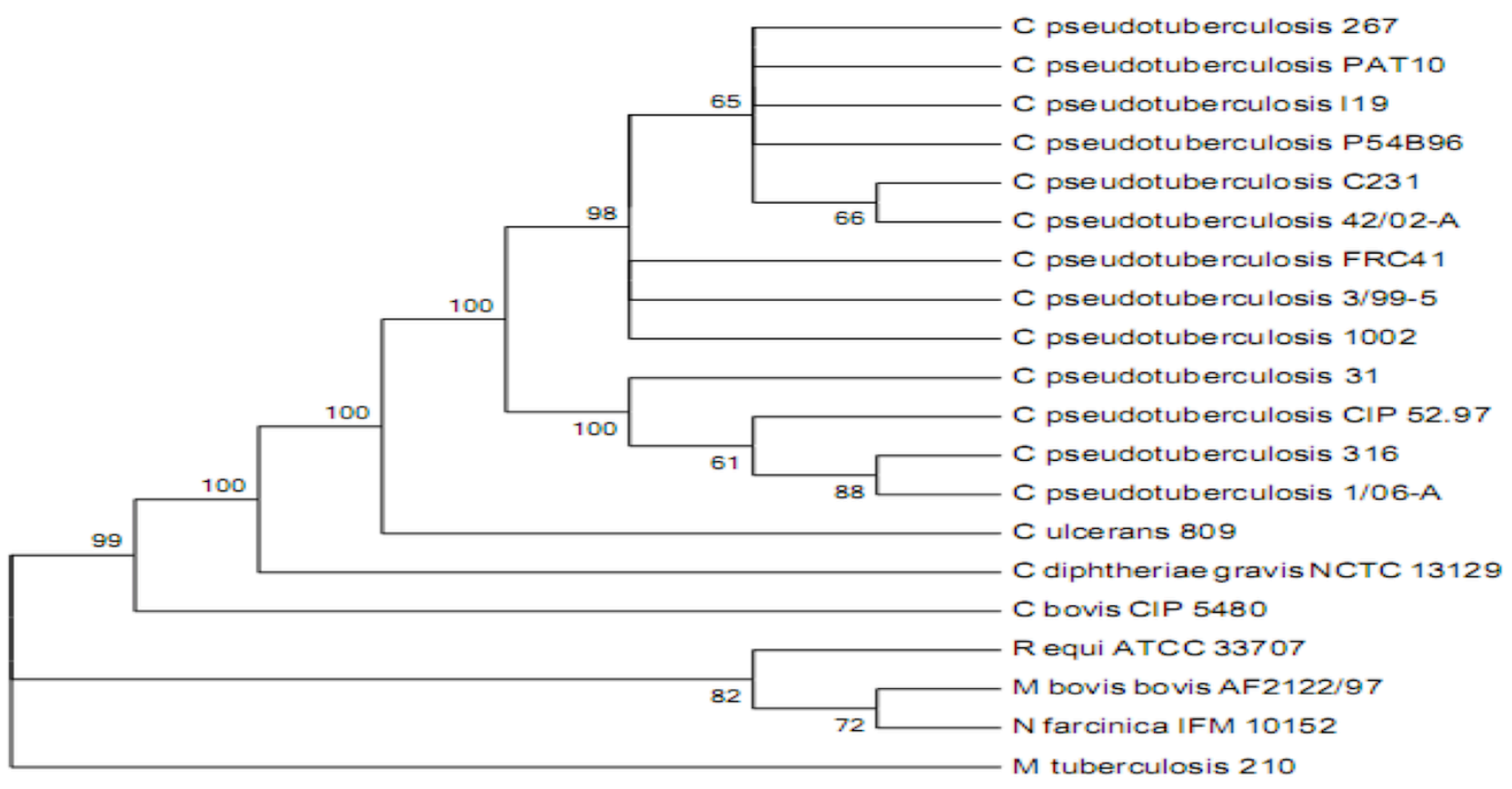

Figure 1. Phylogenetic tree of C. pseudotuberculosis strain P54B96 representing its position relative to type strains in Corynebacteriaceae along with some other type strains of CMNR group. The tree was inferred from 3,537 aligned characters of the $r p o B$ gene sequence using maximum likelihood method and then checked for its agreement with the current classification Table 1. The branch lengths represent the expected number of substitutions per site. Numbers adjacent to the branches are support values from 1,000 bootstrap replicates, indicated when Larger than 60\%. Calculations to determine the phylogenetic distances were done by the software MEGA v5 [30]. 


\begin{tabular}{|c|c|c|c|}
\hline MIGS ID & Property & Term & Evidence code \\
\hline & Classification & Domain Bacteria & TAS [32] \\
\hline & & Phylum Actinobacteria & TAS [33] \\
\hline & & Class Actinobacteria & TAS [34] \\
\hline & & Order Actinomycetales & TAS [34-37] \\
\hline & & Suborder Corynebacterineae & \\
\hline & & Family Corynebacteriaceae & TAS $[34,35,37,38]$ \\
\hline & & Genus Corynebacterium & TAS $[35,38,39]$ \\
\hline & & Species Corynebacterium pseudotuberculosis & TAS $[35,40]$ \\
\hline & & Strain P54B96 & TAS [11] \\
\hline & Gram stain & Positive & TAS [21] \\
\hline & Cell shape & pleomorphic forms & TAS [21] \\
\hline & Motility & non-motile & TAS [8] \\
\hline & Sporulation & non-sporulating & TAS [22] \\
\hline & Temperature range & mesophilic & TAS $[8,22]$ \\
\hline & Optimum temperature & $37^{\circ} \mathrm{C}$ & TAS $[8,22]$ \\
\hline & Salinity & not reported & NAS \\
\hline \multirow[t]{3}{*}{ MIGS-22 } & Oxygen requirement & aerobic and facultatively anaerobic & TAS $[8,22]$ \\
\hline & Carbon source & glucose, fructose, maltose, mannose, and sucrose & TAS [8] \\
\hline & Energy source & hemoorganotroph & TAS [8] \\
\hline MIGS-6 & Habitat & Host & TAS [22] \\
\hline MIGS-15 & Biotic relationship & intracellular facultative pathogen & TAS [22] \\
\hline \multirow[t]{3}{*}{ MIGS-14 } & Pathogenicity & sheep, goats, horses and cattle, rarely humans & TAS $[5,6]$ \\
\hline & Biosafety level & 2 & TAS [22] \\
\hline & Isolation & liver, lung, mediastinal lymph node lesions of antelope & TAS [11] \\
\hline MIGS-4 & Geographic location & Mpumalanga province, South Africa & TAS [11] \\
\hline MIGS-5 & Sample collection time & 2009 & TAS [11] \\
\hline MIGS-4.1 & Latitude & not reported & \\
\hline MIGS-4.2 & Longitude & not reported & \\
\hline MIGS-4.3 & Depth & not reported & \\
\hline MIGS-4.4 & Altitude & not reported & \\
\hline
\end{tabular}

Evidence codes - IDA: Inferred from Direct Assay (first time in publication); TAS: Traceable Author Statement (i. e. a direct report exists in the literature); NAS: Non-traceable Author Statement (i. e. not directly observed for the living, isolated sample, but based on a generally accepted property for the species, or anecdotal evidence). These evidence codes are from the Gene Ontology project [41]. If the evidence code is IDA, then the property was directly observed for a living isolate by one of the authors or an expert mentioned in the acknowledgements. 
Table 2. Genome sequencing project information

\begin{tabular}{lll}
\hline MIGS ID & Property & Term \\
\hline MIGS-31 & Finishing quality & Finished \\
MIGS-28 & Libraries used & Fragments (mean size 112 bp) \\
MIGS-29 & Sequencing platforms & Semiconductor Ion Torrent PGM \\
MIGS-30 & Assemblers & 35-fold \\
MIGS-32 & Gene calling method & CLC Genome Workbench 4.7.2, Velvet \\
& INSDC ID & CP003385 (chromosome) \\
& GenBank Date of Release & April 05, 2012 \\
& GOLD ID & Gc02176 \\
& NCBI project ID & 77871 \\
& Database: IMG-GEBA & 2512564058 \\
MIGS-13 & Source material identifier & BHI broth, P54B96 \\
& Project relevance & Animal Pathogen, Medical \\
\hline
\end{tabular}

For homopolymer correction, an inherent problem of the Ion Torrent [46], CLCBio Genome Workbench 4.7.2 was used. Having detected a high number of frameshifts, manual curation was required prior to analysis to prevent falsepositive identification of pseudogenes. The genome of P54B96 strain consists of 2,337,657 bp circular chromosome and the average $\mathrm{G}+\mathrm{C}$ content of the chromosome is $52.2 \%$. The genome was predicted to contain 2,084 coding sequences (CDS), four rRNA operons, 49 tRNA and 62 pseudogenes.

\section{Genome annotation}

For automatic annotation, different programs were used. These include; Glimmer: gene predictor [47], RNAmmer: rRNA predictor [48]; tRNAscan-SE: tRNA predictor [49]; and Tandem Repeat Finder: repetitive DNA predictor [50]. Functional annotation was performed by similarity analyses, using public databases of National Center for Biotechnology Information (NCBI) non-redundant database, Pfam and InterProScan software [51], which integrates multiple domain and protein family databases. Manual annotation was performed using Artemis [52].

\section{Metabolic network analysis}

The metabolic Pathway/Genome Database (PGDB) was computationally generated using Pathway Tools software version 15.0 [53] and MetaCyc version 15.0 [54], based on annotated EC numbers and a customized enzyme name mapping file. There has been no manual curation in the database and it may contain errors, similar to a Tier 3 BioCyc PGDB [55].

\section{Genome properties}

The genome is 2,337,657 bp long and comprises one main circular chromosome with a $52.19 \%$ GC content. A total of 2,207 genes were predicted, among which 2,146 were protein coding genes, and 61 RNAs; 62 pseudogenes were also identified. Of the whole genome, 69.01\% comprise genes that were assigned with putative functions, while the remaining genes were annotated as hypothetical proteins. The properties and statistics of the C. pseudotuberculosis genome are listed in Table 3. The distributions of genes into COGs functional categories is presented in Figure 2 and Table 4 , followed by a cellular overview diagram in Figure 3 and a summary of metabolic network statistics shown in Table 5. 
Table 3. Genome Statistics

\begin{tabular}{lrr}
\hline Attribute & Value & \% of Total \\
\hline Genome size (bp) & $2,337,657$ & $100.00 \%$ \\
DNA coding region (bp) & $2,005,391$ & $85.79 \%$ \\
DNA G+C content (bp) & $1,219,912$ & $52.19 \%$ \\
Number of replicons & 1 & \\
Extrachromosomal elements & 0 & \\
Total genes & 2,145 & $100.00 \%$ \\
RNA genes & 61 & $2.76 \%$ \\
rRNA operons & 4 & \\
Protein-coding genes & 2,084 & $97.16 \%$ \\
Pseudo genes & 62 & $2.81 \%$ \\
Genes with function prediction & 1,511 & $68.46 \%$ \\
Genes in paralog clusters & 425 & $19.26 \%$ \\
Genes assigned to COGs & 1,552 & $70.32 \%$ \\
Genes assigned Pfam domains & 1,596 & $72.32 \%$ \\
Genes with signal peptides & 651 & $29.50 \%$ \\
Genes with transmembrane helices & 584 & $26.46 \%$ \\
CRISPR repeats & 0 & \\
\hline
\end{tabular}

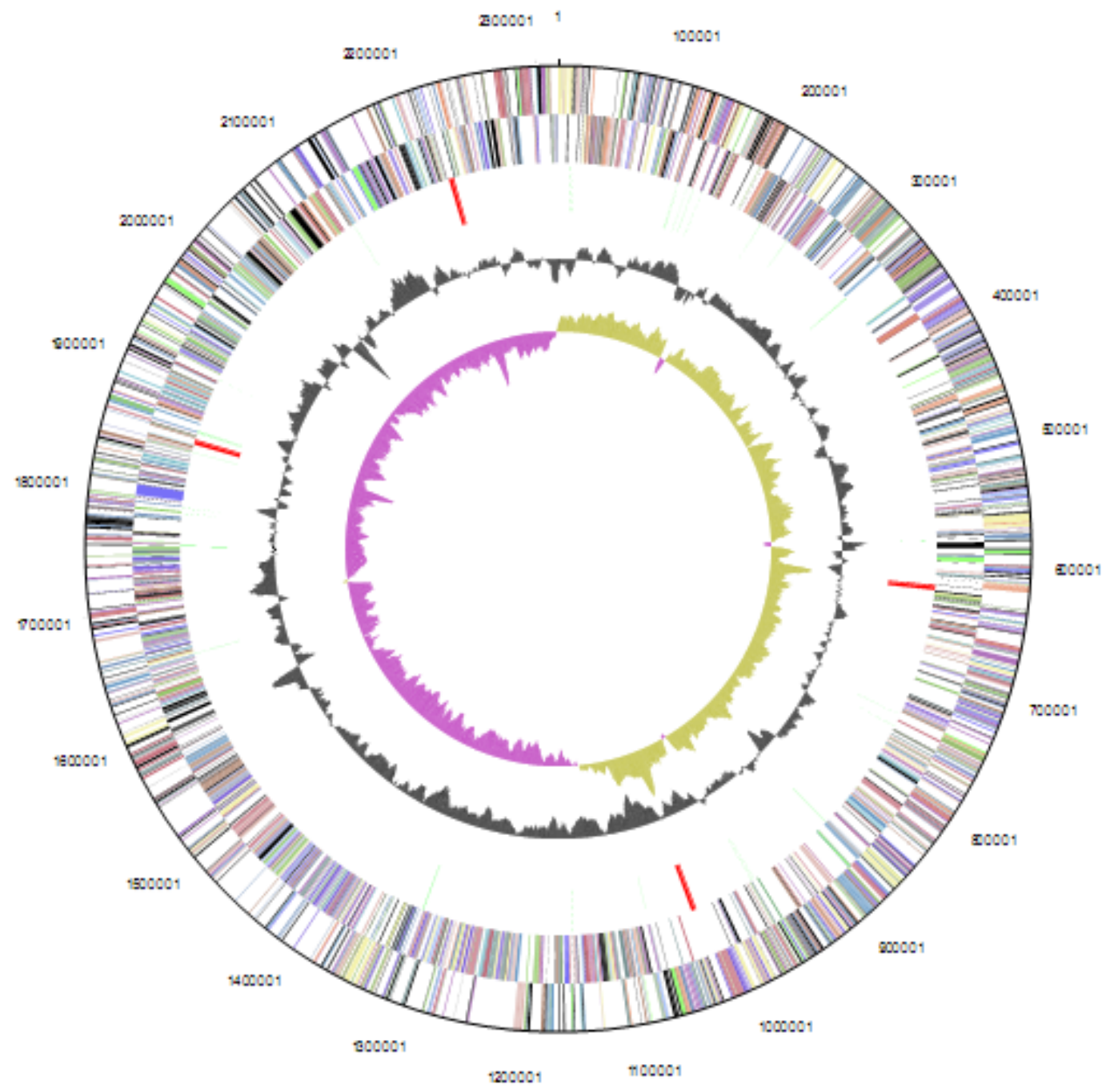

Figure 2.Graphical circular map of the genome. From outside to the center: Genes on forward strand (color by COG categories), Genes on reverse strand (color by COG categories), RNA genes (tRNAs green, rRNAs red, other RNAs black), GC content, GC skew. 
Table 4. Number of genes associated with the general COG functional categories

\begin{tabular}{crrl}
\hline Code & Value & \%age & Description \\
\hline J & 140 & 6.72 & Translation, ribosomal structure and biogenesis \\
A & 1 & 0.1 & RNA processing and modification \\
K & 121 & 5.8 & Transcription \\
L & 88 & 4.2 & Replication, recombination and repair \\
B & 0 & 0.0 & Chromatin structure and dynamics \\
D & 21 & 1.0 & Cell cycle control, cell division, chromosome partitioning \\
Y & 0 & 0.0 & Nuclear structure \\
V & 25 & 1.2 & Defense mechanisms \\
T & 54 & 2.6 & Signal transduction mechanisms \\
M & 87 & 4.2 & Cell wall/membrane biogenesis \\
N & 1 & 0.1 & Cell motility \\
Z & 0 & 0.0 & Cytoskeleton \\
W & 0 & 0.0 & Extracellular structures \\
U & 27 & 1.3 & Intracellular trafficking and secretion \\
O & 77 & 3.7 & Posttranslational modification, protein turnover, chaperones \\
C & 90 & 4.3 & Energy production and conversion \\
G & 113 & 5.4 & Carbohydrate transport and metabolism \\
E & 177 & 8.5 & Amino acid transport and metabolism \\
F & 73 & 3.5 & Nucleotide transport and metabolism \\
H & 102 & 4.9 & Coenzyme transport and metabolism \\
I & 57 & 2.7 & Lipid transport and metabolism \\
P & 122 & 5.9 & Inorganic ion transport and metabolism \\
Q & 26 & 1.3 & Secondary metabolites biosynthesis, transport and catabolism \\
R & 169 & 8.1 & General function prediction only \\
S & 136 & 6.5 & Function unknown \\
- & 655 & 31.4 & Not in COGs \\
\hline
\end{tabular}

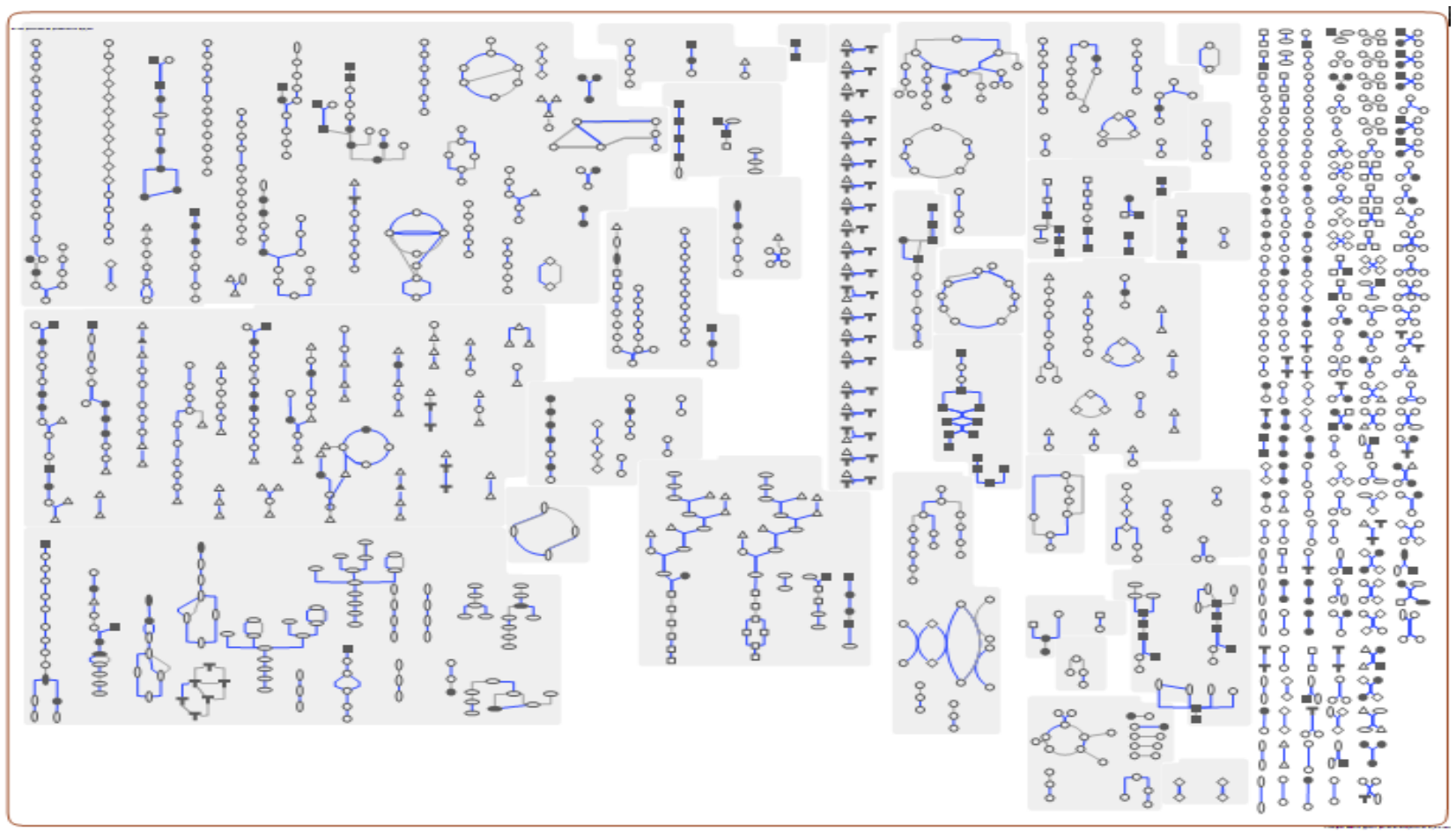

Figure 3. Schematic cellular overview of all pathways of the C. pseudotuberculosis P54B96 metabolism. Nodes represent metabolites, with shape indicating class of metabolite. Lines represent reactions. 


\begin{tabular}{lc}
\multicolumn{2}{l}{ Table 5. Metabolic Network Statistics } \\
\hline Attribute & Value \\
\hline Total genes & 2,145 \\
Enzymes & 500 \\
Enzymatic reactions & 764 \\
Metabolic pathways & 152 \\
Metabolites & 622 \\
\hline
\end{tabular}

\section{Acknowledgement}

We would like to gratefully acknowledge the help of all the team members \& the financing agencies. Hassan S.S acknowledges the receipt of a Scholarship from the CNPq under the "TWAS-CNPq Postgraduate Fellowship Programme" for doctoral studies. This work was partially executed by Rede Paraense de Genômica e Proteômica supported by FAPESPA (Fundação de

\section{References}

1. Williamson LH. Caseous lymphadenitis in small ruminants. [vii.]. Vet Clin North Am Food Anim Pract 2001; 17:359-371. PubMed

2. Dorella FA, Pacheco LG, Oliveira SC, Miyoshi A, Azevedo V. Corynebacterium pseudotuberculosis: microbiology, biochemical properties, pathogenesis and molecular studies of virulence. Vet Res 2006; 37:201-218. PubMed http://dx.doi.org/10.1051/vetres:2005056

3. Ayers JL. Caseous lymphadenitis in goats and sheep: a review of diagnosis, pathogenesis, and immunity. J Am Vet Med Assoc 1977; 171:12511254. PubMed

4. Marchand $\mathrm{CH}$, Salmeron $\mathrm{C}$, Raad RB, Meniche X, Chami M, Masi M, Blanot D, Daffe M, Tropis M, Huc E, et al. Biochemical disclosure of the mycolate outer membrane of Corynebacterium glutamicum. J Bacteriol 2012; 194:587-597. PubMed http://dx.doi.org/10.1128/JB.06138-11

5. Brown CC, Olander HJ, Alves SF. Synergistic hemolysis-inhibition titers associated with caseous lymphadenitis in a slaughterhouse survey of goats and sheep in Northeastern Brazil. Can / Vet Res 1987; 51:46-49. PubMed

6. Lipsky BA, Goldberger AC, Tompkins LS, Plorde JJ. Infections caused by nondiphtheria corynebacteria. Rev Infect Dis 1982; 4:12201235. PubMed http://dx.doi.org/10.1093/clinids/4.6.1220

7. Aleman M, Spier SJ, Wilson WD, Doherr M. Corynebacterium pseudotuberculosis infection in
Amparo à Pesquisa do Estado do Pará), CNPq (Conselho Nacional de Desenvolvimento Científico e Tecnológico, Brasil), CAPES (Coordenação de Aperfeiçoamento de Pessoal de Nível Superior, Brasil) and FAPEMIG (Fundação de Amparo à Pesquisa do Estado de Minas Gerais, Brasil).

horses: 538 cases (1982-1993). J Am Vet Med Assoc 1996; 209:804-809. PubMed

8. Merchant IA, Packer RA. Veterinary bacteriology and virology. Ames: lowa State University Press; 1967 , p. 752 .

9. Piontkowski MD, Shivvers DW. Evaluation of a commercially available vaccine against Corynebacterium pseudotuberculosis for use in sheep. J Am Vet Med Assoc 1998; 212:17651768. PubMed

10. Trost E, Ott L, Schneider J, Schroder J, Jaenicke S, Goesmann A, Husemann P, Stoye J, Dorella FA, Rocha FS, et al. The complete genome sequence of Corynebacterium pseudotuberculosis FRC41 isolated from a 12-year-old girl with necrotizing lymphadenitis reveals insights into generegulatory networks contributing to virulence. BMC Genomics 2010; 11:728. PubMed http://dx.doi.org/10.1186/1471-2164-11-728

11. Müller B, de Klerk-Lorist LM, Henton MM, Lane E, Parsons S, Gey van Pittius NC, Kotze A, van Helden PD, Tanner M. Mixed infections of Corynebacterium pseudotuberculosis and nontuberculous mycobacteria in South African antelopes presenting with tuberculosis-like lesions. Vet Microbiol 2011; 147:340-345. PubMed http://dx.doi.org/10.1016/j.vetmic.2010.07.017

12. Connor KM, Quirie MM, Baird G, Donachie W. Characterization of United Kingdom isolates of Corynebacterium pseudotuberculosis using pulsed-field gel electrophoresis. J Clin Microbiol 2000; 38:2633-2637. PubMed 
13. Ben Saïd MS, Ben Maitigue $H$, Benzarti $M$, Messadi L, Rejeb A, Amara A. Epidemiological and clinical studies of ovine caseous lymphadenitis. Arch Inst Pasteur Tunis 2002; 79:51-57. PubMed

14. Binns SH, Bailey M, Green LE. Postal survey of ovine caseous lymphadenitis in the United Kingdom between 1990 and 1999. Vet Rec 2002;

150:263-268. PubMed http://dx.doi.org/10.1136/vr.150.9.263

15. Arsenault J, Girard C, Dubreuil P, Daignault D, Galarneau JR, Boisclair J, Simard C, Belanger D. Prevalence of and carcass condemnation from maedi-visna, paratuberculosis and caseous lymphadenitis in culled sheep from Quebec, Canada. Prev Vet Med 2003; 59:67-81. PubMed http://dx.doi.org/10.1016/S0167-5877(03)00060$\underline{6}$

16. Paton MW, Walker SB, Rose IR, Watt GF. Prevalence of caseous lymphadenitis and usage of caseous lymphadenitis vaccines in sheep flocks. Aust Vet J 2003; 81:91-95. PubMed http://dx.doi.org/10.1111/j.17510813.2003.tb11443.x

17. Selim SA. Oedematous skin disease of buffalo in Egypt. / Vet Med B Infect Dis Vet Public Health 2001; 48:241-258. PubMed http://dx.doi.org/10.1046/j.1439$\underline{0450.2001 .00451 . x}$

18. Pinheiro RRGA, Alves FSF, Haddad JP. Aspectos epidemiológicos da caprinocultura cearense. Arquivo Brasileiro Med Veterinaria Zootecnia 2000; 52:10. http://dx.doi.org/10.1590/S010209352000000500021

19. Barakat AASSA, Atef A, Saber MS, Nafie EK. Two serotypes of Corynebacterium pseudotuberculosis isolated from different animal species. Revue Scientifique et Technique Office International des Epizooties 1984; 3:151-163.

20. Hard GC. Electron microscopic examination of Corynebacterium ovis. J Bacteriol 1969; 97:14801485. PubMed

21. Jones DCM. Irregular, nonsporing Gram-positive rods. In: Smeath PHA, Mair NS, Sharpe ME, Holt JG (eds), Bergey's Manual of Systematic Bacteriology. Williams and Wilkins, Baltimore; 1986, p. 1261.

22. Buxton A, Fraser G. Corynebacterium. In: Buxton A, Fraser G (eds) Animal Microbiology. Blackwell Scientific Publications, Edinburgh, 1977, p. 177.
23. Muckle CA, Gyles CL. Characterization of strains of corynebacterium pseudotuberculosis. Can J Comp Med 1982; 46:206-208. PubMed

24. Biberstein EL, Knight HD, Jang S. Two biotypes of Corynebacterium pseudotuberculosis. Vet Rec 1971; 89:691-692. PubMed http://dx.doi.org/10.1136/vr.89.26.691

25. Bayan N, Houssin C, Chami M, Leblon G. Mycomembrane and S-layer: two important structures of Corynebacterium glutamicum cell envelope with promising biotechnology applications. J Biotechnol 2003; 104:55-67. PubMed http://dx.doi.org/10.1016/S0168-1656(03)00163$\underline{9}$

26. De Sousa-D'Auria C, Kacem R, Puech V, Tropis M, Leblon G, Houssin C, Daffe M. New insights into the biogenesis of the cell envelope of corynebacteria: identification and functional characterization of five new mycoloyltransferase genes in Corynebacterium glutamicum. FEMS Microbiol Lett 2003; 224:35-44. PubMed http://dx.doi.org/10.1016/S0378-1097(03)00396$\underline{3}$

27. Puech V, Chami M, Lemassu A, Laneelle MA, Schiffler B, Gounon P, Bayan N, Benz R, Daffe M. Structure of the cell envelope of corynebacteria: importance of the non-covalently bound lipids in the formation of the cell wall permeability barrier and fracture plane. Microbiology 2001; 147:1365-1382. PubMed

28. Gebhardt H, Meniche X, Tropis M, Kramer R, Daffe M, Morbach S. The key role of the mycolic acid content in the functionality of the cell wall permeability barrier in Corynebacterineae. Microbiology 2007; 153:1424-1434. PubMed http://dx.doi.org/10.1099/mic.0.2006/003541-0

29. Songer JG, Beckenbach K, Marshall MM, Olson GB, Kelley L. Biochemical and genetic characterization of Corynebacterium pseudotuberculosis. Am J Vet Res 1988; 49:223-226. $\underline{\text { PubMed }}$

30. Tamura K, Peterson D, Peterson N, Stecher G, Nei M, Kumar S. MEGA5: molecular evolutionary genetics analysis using maximum likelihood, evolutionary distance, and maximum parsimony methods. Mol Biol Evol 2011; 28:2731-2739. $\underline{\text { PubMed }}$ http://dx.doi.org/10.1093/molbev/msr121

31. Field D, Garrity G, Gray T, Morrison N, Selengut J, Sterk P, Tatusova T, Thomson N, Allen MJ, Angiuoli SV, et al. The minimum information about a genome sequence (MIGS) specification. 
Nat Biotechnol 2008; 26:541-547. PubMed http://dx.doi.org/10.1038/nbt1360

32. Woese CR, Kandler O, Wheelis ML. Towards a natural system of organisms: proposal for the domains Archaea, Bacteria, and Eucarya. Proc Natl Acad Sci USA 1990; 87:4576-4579. PubMed http://dx.doi.org/10.1073/pnas.87.12.4576

33. Garrity GM, Holt JG. The Road Map to the Manual. In: Garrity GM, Boone DR, Castenholz RW (eds), Bergey's Manual of Systematic Bacteriology, Second Edition, Volume 1, Springer, New York, 2001, p. 119-169.

34. Stackebrandt E, Rainey FA, Ward-Rainey NL. Proposal for a new hierarchic classification system, Actinobacteria classis nov. Int J Syst Bacteriol 1997; 47:479-491. http://dx.doi.org/10.1099/00207713-47-2-479

35. Skerman VBD, McGowan V, Sneath PHA. Approved Lists of Bacterial Names. Int J Syst Bacteriol 1980; 30:225-420. http://dx.doi.org/10.1099/00207713-30-1-225

36. Buchanan RE. Studies in the nomenclature and classification of bacteria. II. The primary subdivisions of the Schizomycetes. J Bacteriol 1917; 2:155-164. PubMed

37. Zhi XY, Li WJ, Stackebrandt E. An update of the structure and 16S rRNA gene sequence-based definition of higher ranks of the class Actinobacteria, with the proposal of two new suborders and four new families and emended descriptions of the existing higher taxa. Int I Syst Evol Microbiol 2009; 59:589-608. PubMed http://dx.doi.org/10.1099/ijs.0.65780-0

38. Lehmann KB, Neumann R. Lehmann's Medizin, Handatlanten. X Atlas und Grundriss der Bakteriologie und Lehrbuch der speziellen bakteriologischen Diagnostik., Fourth Edition, Volume 2, J.F. Lehmann, München, 1907, p. 270.

39. Bernard KA, Wiebe D, Burdz T, Reimer A, Ng B, Singh C, Schindle S, Pacheco AL. Assignment of Brevibacterium stationis (ZoBell and Upham 1944) Breed 1953 to the genus Corynebacterium, as Corynebacterium stationis comb. nov., and emended description of the genus Corynebacterium to include isolates that can alkalinize citrate. Int J Syst Evol Microbiol 2010; 60:874-879. PubMed http://dx.doi.org/10.1099/ijs.0.012641-0

40. Eberson F. A bacteriologic study of the diphtheroid organisms with special reference to Hodgkin's disease. J Infect Dis 1918; 23:1-42.
41. Ashburner M, Ball CA, Blake JA, Botstein D, Butler $\mathrm{H}$, Cherry JM, Davis AP, Dolinski K, Dwight SS, Eppig JT, et al. Gene ontology: tool for the unification of biology. The Gene Ontology Consortium. Nat Genet 2000; 25:25-29. PubMed http://dx.doi.org/10.1038/75556

42. Khamis A, Raoult D, La Scola B. rpoB gene sequencing for identification of Corynebacterium species. J Clin Microbiol 2004; 42:3925-3931. PubMed

http://dx.doi.org/10.1128/JCM.42.9.3925$\underline{3931.2004}$

43. Khamis A, Raoult D, La Scola B. Comparison between rpoB and $16 \mathrm{~S}$ rRNA gene sequencing for molecular identification of 168 clinical isolates of Corynebacterium. J Clin Microbiol 2005;

43:1934-1936. PubMed http://dx.doi.org/10.1128/JCM.43.4.19341936.2005

44. Liolios K, Chen IM, Mavromatis K, Tavernarakis N, Hugenholtz P, Markowitz VM, Kyrpides NC. The Genomes On Line Database (GOLD) in 2009: status of genomic and metagenomic projects and their associated metadata. Nucleic Acids Res 2010; 38(Database issue):D346-D354. PubMed http://dx.doi.org/10.1093/nar/gkp848

45. Cerdeira LT, Carneiro AR, Ramos RT, de Almeida SS, D'Afonseca V, Schneider MP, Baumbach J, Tauch A, McCulloch JA, Azevedo VA, et al. Rapid hybrid de novo assembly of a microbial genome using only short reads: Corynebacterium pseudotuberculosis 119 as a case study. J Microbiol Methods 2011; 86:218-223. PubMed http://dx.doi.org/10.1016/j.mimet.2011.05.008

46. Mellmann A, Harmsen D, Cummings CA, Zentz EB, Leopold SR, Rico A, Prior K, Szczepanowski $\mathrm{R}$, Ji $\mathrm{Y}$, Zhang $\mathrm{W}$, et al. Prospective genomic characterization of the German enterohemorrhagic Escherichia coli O104:H4 outbreak by rapid next generation sequencing technology. PLOS ONE 2011; 6:e22751. PubMed http://dx.doi.org/10.1371/journal.pone.0022751

47. Delcher AL, Harmon D, Kasif S, White O, Salzberg SL. Improved microbial gene identification with GLIMMER. Nucleic Acids Res 1999;

27:4636-4641. PubMed http://dx.doi.org/10.1093/nar/27.23.4636

48. Lagesen K, Hallin P, Rodland EA, Staerfeldt HH, Rognes T, Ussery DW. RNAmmer: consistent and rapid annotation of ribosomal RNA genes. Nucleic Acids Res 2007; 35:3100-3108. PubMed http://dx.doi.org/10.1093/nar/gkm160 
Hassan et al.

49. Lowe TM, Eddy SR. tRNAscan-SE: a program for improved detection of transfer RNA genes in genomic sequence. Nucleic Acids Res 1997;

25:955-964. PubMed

50. Benson G. Tandem repeats finder: a program to analyze DNA sequences. Nucleic Acids Res 1999; 27:573-580. PubMed

http://dx.doi.org/10.1093/nar/27.2.573

51. Zdobnov EM, Apweiler R. InterProScan--an integration platform for the signature-recognition methods in InterPro. Bioinformatics 2001; 17:847848. PubMed http://dx.doi.org/10.1093/bioinformatics/17.9.847

52. Rutherford K, Parkhill J, Crook J, Horsnell T, Rice P, Rajandream MA, Barrell B. Artemis: sequence visualization and annotation. Bioinformatics 2000; 16:944-945. PubMed http://dx.doi.org/10.1093/bioinformatics/16.10.94 $\underline{4}$
53. Karp PD, Paley S, Romero P. The Pathway Tools software. Bioinformatics 2002; 18(Suppl 1):S225S232. PubMed

http://dx.doi.org/10.1093/bioinformatics/18.suppl 1.S225

54. Caspi R, Foerster $H$, Fulcher CA, Kaipa P, Krummenacker M, Latendresse M, Paley S, Rhee SY, Shearer AG, Tissier C, et al. The MetaCyc Database of metabolic pathways and enzymes and the BioCyc collection of Pathway/Genome Databases. Nucleic Acids Res 2007; 36(Database issue):D623-D631. PubMed http://dx.doi.org/10.1093/nar/gkm900

55. Karp PD, Ouzounis CA, Moore-Kochlacs C, Goldovsky L, Kaipa P, Ahren D, Tsoka S, Darzentas N, Kunin V, Lopez-Bigas N. Expansion of the BioCyc collection of pathway/genome databases to 160 genomes. Nucleic Acids Res 2005; 33:6083-6089. PubMed http://dx.doi.org/10.1093/nar/gki892 